\title{
STRATEGI PENGAMANAN JANGKA PANJANG PENGGUNAAN LAHAN DAN AIR
}

\author{
(Long Term Strategy for Sustaining Land and Water Utilization)
}

\author{
Oleh / By : \\ Ag. Pudjiharta*
}

\begin{abstract}
Water is one of the environmental elements that can not be separated from other natural resources, like land, climate, forest, and social and culture of communities. Therefore, the planning of the utilization and management of land and water resources can not be separated from the planning of watershed development which is based on physical characteristic of watershed, hydrology, climate, social and culture and the demand and supply of natural resources. Integrated development is important for flood control, conservation and rehabilitation of recharge and head water catchment areas, rural development, social forestry, water supply and drainage facilities.
\end{abstract}

Keywords : Management, utilization, land, water

\begin{abstract}
ABSTRAK
Air adalah bagian dari lingkungan dan tidak dapat dipisahkan dari sumber daya alam lainnya, seperti lahan, iklim, sumber daya hutan dan lingkungan sosial budaya masyarakat. Dari kenyataan tersebut perencanaan mengenai penggunaan dan pengelolaan sumber daya lahan dan air tidak dapat dipisahkan dari perencanaan tata ruang dan penataan kawasan pada sistem daerah aliran sungai yang didasarkan atas karakteristik biofisik, hidrologi, iklim, sosial budaya dan persediaan serta kebutuhan akan sumber daya alam. Penggunaan terpadu lebih diutamakan untuk pengendalian banjir, konservasi dan rehabilitasi daerah resapan air dan daerah hulu, pembangunan pedesaan, perhutanan sosial, fasilitas penyediaan air, dan fasilitas drainase.
\end{abstract}

Kata kunci: Pengelolaan, penggunaan, lahan, air

\section{PENDAHULUAN}

Banjir dan kekeringan silih berganti setiap tahun sebagai konsekwensi pergantian musim di Indonesia. Musim penghujan dengan ciri-ciri banyak hujan, ancaman banjir dan tanah longsor. Musim kemarau dengan ciri-ciri sedikit hujan, kekurangan air, penurunan debit mata air dan penurunan debit sungai dan ancaman kebakaran. Kondisi yang kontradiktif tersebut terjadi setiap tahun dengan tingkat kekeringan dan atau banjir yang bervariasi bahkan dapat berulang pada periode tertentu. Kekeringan yang terasa berat terjadi pada tahun 1991, 1993/1994, 1997, 2000/2001, dan 2003 dan banjir besar pada tahun 1992, 1996, 1999, 2002, dan 2003, tampaknya ada periode ulang 3 tahunan timbul kekeringan.

\footnotetext{
* Peneliti pada Pusat Litbang Hutan dan Konservasi Alam, Bogor
} 
Berdasarkan kondisi seperti di atas, maka penggunaan lahan dan air semestinya dipertimbangkan dengan kondisi tersebut. Karena kondisi tersebut merupakan hal yang rutin yang selalu dapat terjadi. Kejadian banjir dan kekeringan/kekurangan air yang silih berganti setiap tahun sejalan dengan pergantian musim, merupakan indikasi bahwa telah terjadi kerusakan sistem tata air (sistem hidrologi) sebagai akibat tata guna lahan yang mempengaruhi sistem tata air sehingga terjadi ketidakseimbangan hidrologi. Kondisi tersebut diperberat lagi oleh keterbatasan sumber air bersih, meningkatnya jumlah penduduk, meningkatnya kebutuhan air, meningkatnya aktivitas manusia, meningkatnya kontaminasi, meningkatnya biaya proyek-proyek air bersih, meningkatnya teknologi pembuangan polutan (Anonim, 1991)

Perhatian terhadap kualitas lingkungan telah berkembang akibat beragamnya desakan kebutuhan-kebutuhan akan material dan psikologis yang terus meningkat karena tekanan penduduk. Perhatian utama adalah adanya pengaruh pengelolaan lahan dan tata guna lahan terhadap kualitas, kuantitas dan ketersediaan air, hutan dan kemantapan ekologis. Ketersediaan sumber daya air yang cukup, menjadi perhatian utama pada daerah beriklim kering (curah hujan kecil) maka upaya meminimalkan kehilangan air menjadi prioritas, sebaliknya pada daerah beriklim basah (banyak hujan) perhatian utama adalah meminimalkan ancaman banjir, erosi tanah dan tanah longsor.

Hutan sebagai salah satu dari faktor hidrologi adalah faktor yang peka terhadap aktivitas manusia sehingga mudah mengalami perubahan yang cenderung menuju penurunan fungsi sebagai faktor hidrologi. Hutan sebagai faktor alami pengendali aliran, kemampuannya tidak tak terbatas, tetapi dipengaruhi/bergantung pada besarnya curah hujan (lama dan intensitas), geologi/tanah dan topografi/lereng. Apabila kondisi hutan pada daerah hulu daerah aliran sungai (DAS) yang umumnya merupakan wilayah bergunung/pegunungan kondisinya baik diharapkan kondisi tata airnya baik.

Dalam tulisan ini dikemukakan kaitan hutan dengan upaya pengamanan tata guna lahan dan penyediaan air jangka panjang, meliputi (1) Identifikasi jenis pohon/tanaman yang hemat air, (2) Rehabilitasi hutan dalam kaitannya dengan penyerapan air oleh tanah, (3) Reboisasi/rehabilitasi daerah resapan, (4) Banjir-kekeringan-tanah longsor dan (5) Tata guna lahan dan air jangka panjang.

\section{IDENTIFIKASI JENIS POHON/TANAMAN YANG HEMAT AIR}

Pada prinsipnya semua jenis pohon dapat membantu dalam proses penyimpanan air dalam tanah, tetapi semua pohon/tanaman juga membutuhkan air untuk tumbuh dan berkembang. Upaya yang penting dalam hal ini adalah memilih jenis-jenis pohon/tanaman yang menggunakan/ memerlukan air yang efisien.

Ada beberapa faktor dari pohon/tanaman yang mempengaruhi besar atau kecilnya penggunaan/pengambilan air antara lain : massa tanaman (bio massa), diameter pembuluh, panjang elemen pembuluh (Februari etal., 1995).

Air yang naik sampai tajuk (daun) yang tidak dimanfaatkan dalam proses fotosintesa akan keluar menguap melalui mulut daun. Jumlah mulut daun per satuan luas mempengaruhi laju penguapan (transpirasi).

Penguapan air melalui mulut daun dipengaruhi oleh elastisitas anatomi daun. Pada jenis pohon/tanaman yang anatomi daun elastis pada suhu tertentu akan mempersempit /menutup mulut daun untuk mengurangi penguapan, jenis ini antara lain : eucalyptus. 
Ada jenis pohon/tanaman yang menggugurkan daun pada periode musim kemarau untuk mengurangi pengguapan, jenis tersebut antara lain : Swietenia macrophylla.

Ada jenis tanaman yang masuk golongan $\mathrm{C}_{4}$ atau 4 carbon asam organik. Jenis golongan $\mathrm{C}_{4}$ ini nilai pertukaran $\mathrm{CO}_{2}$ relatif tinggi dan membutuhkan suhu (radiasi) matahari relatif tinggi dalam proses photosintesa, dibandingkan dengan jenis tanaman golongan $\mathrm{C}_{3}$ atau 3 carbon asam organik. Dengan demikian secara teoritis jenis tanaman $\mathrm{C}_{4}$ akan membutuhkan air $\left(\mathrm{H}_{2} \mathrm{O}\right)$ relatif tinggi. Termasuk tanaman golongan $\mathrm{C}_{4}$ antara lain : sorgum, jagung, dan tebu, sedangkan tanaman golongan $\mathrm{C}_{3}$ antara lain : gandum, kentang putih, kedelai, padi, kapas, dan kentang manis.

Fungsi pohon/tanaman dalam siklus air melalui 4 proses yaitu : (1) Intersepsi (interception), (2)Air lolos (through fall), (3) Aliran batang (stem flow) dan (4) Evapotranspirasi (evapotranspiration).

Bagian air hujan yang tercegat tajuk (intersepsi tajuk) dan air hujan yang berada dipermukaan bagian-bagian tanaman/pohon akan menguap, sehingga bagian air ini termasuk komponen air hilang, sedangkan air hujan yang mengalir melalui batang (aliran batang) dan air yang lolos dari cegatan tajuk (air lolos) merupakan komponen perolehan air dari air hujan. Aliran batang ditambah air lolos sering disebut : hujan bersih (netto) setelah mencapai permukaan tanah akan mengalami intersepsi oleh serasah. Hujan netto yang lolos dari intersepsi serasah disebut air hujan efektif. Air hujan efektif tersebut mempunyai kesempatan meresap ke dalam profil tanah, maka proses pengisian kelembaban tanah melalui infiltrasi akan berlangsung dan apabila air ini terus merembes memasuki lapisan tanah yang lebih dalam melalui proses perkolasi maka proses pengisian air tanah akan berlangsung. Pengisian sumber air tanah tersebut untuk kesempatan berikutnya akan mengisi/memasok air ke mata air.

Dalam pemilihan jenis pohon/tanaman yang akan ditanam secara luas yang penting adalah : pertimbangan kepada tujuan penanaman tersebut untuk apa, berapa besar curah hujan tahunan daerah yang akan ditanami, nilai evapotranspirasi jenis pohon/tanaman yang akan ditanam dan pola tanam. Nilai evapotranspirasi jenis pohon yang akan ditanam sebaiknya lebih kecil daripada curah hujan tahunan daerah yang akan ditanami, agar dampak negatif terhadap persediaan air oleh adanya penanaman pohon hutan dalam skala luas dapat diminimalkan (Pudjiharta 1997). Peranan beberapa tanaman dalam mendistribusikan air disajikan pada Tabel 1 .

Pohon/tanaman dapat beradaptasi dengan kondisi basah (cukup air) dan kering (kurang air). Pada kondisi cukup air, pohon/tanaman dapat menggunakan air cukup pula, sedang pada kondisi kurang air, tanaman/pohon dapat menyesuaikannya sampai pada kondisi tertentu, itulah sebabnya tanaman/pohon yang berada pada tempat yang cukup air, tumbuhnya lebih baik/subur, daripada yang berada ditempat kurang air.

Selama ini sub sektor yang menderita setiap terjadi terjadi musim kering (kekurangan air) adalah sub sektor pertanian (tanaman semusim) yang pada umumnya berakar dangkal dan sangat peka terhadap kondisi kelembaban permukaan tanah (kedalaman 10-20 cm). Sedangkan kelembaban permukaan tanah sangat peka terhadap pengaruh cuaca (suhu permukaan).

Untuk mengurangi resiko di atas, perlu diformulasikan pola tanam (waktu tanam, jenis tanaman), tanaman campuran (agro forestry) dan hutan rakyat (HKM). Jenis tanaman yang dapat dipilih seperti Maranta arundinaceae (patat sagu/garut), tanaman buah-buahan atau jenis tanaman/pohon serba guna yang ditanam secara campur/tumpang sari, pada hutan HKM atau agro forestry. Sistem tersebut diharapkan dapat mengurangi resiko kerawanan akibat musim kering. 
Tabel 1. Persentase intersepsi, air lolos, aliran batang dan evapotranspirasi beberapa jenis pohon dan jenis tanaman bawah (\% curah hujan)

Table 1. Presentage of interception, through fall, stem flow and evapotranspiration on saveral of tree species and under growth (\% rain fall)

\begin{tabular}{|c|c|c|c|c|c|}
\hline & $\begin{array}{l}\text { Jenis tanaman } \\
\text { (Tree species) }\end{array}$ & $\begin{array}{c}\text { Intersepsi } \\
\text { (Interception) }\end{array}$ & $\begin{array}{c}\text { Air lolos } \\
\text { (Through fall) }\end{array}$ & $\begin{array}{c}\text { Aliran } \\
\text { batang } \\
\text { (Stem flow) }\end{array}$ & $\begin{array}{c}\text { Evapotranspirasi } \\
\text { (Evapotranspiration) }\end{array}$ \\
\hline 1 & $\begin{array}{l}\text { Eucalyptus } \\
\text { camaldulensis }\end{array}$ & 14.6 & 80.8 & 4.5 & - \\
\hline 2 & Eucalyptus saligna & 12.2 & 83.6 & 4.2 & - \\
\hline 3 & Eucalyptus hybrid & 11.6 & 80.7 & 7.6 & 60 \\
\hline 4 & Eucalyptus umbra & 22 & 75 & 3 & - \\
\hline 5 & Pinus merkusii & 32.5 & 48.7 & 28.8 & 5860 \\
\hline 6 & Parkia speciosa & - & - & - & 30 \\
\hline 6 & Swietenia macrophylla & - & - & - & 58 \\
\hline 7 & Kaliandra & - & 5 & - & 44 \\
\hline 7 & Rasamala & - & - & - & 42 \\
\hline 7 & Acacia decurren & - & - & - & 46 \\
\hline 8 & Agathis loranthifolia & 1017 & 7884 & 35 & 33.3 \\
\hline 9 & Dalbergia latifolia & - & - & - & 58 \\
\hline 9 & Shorea pinanga & - & - & - & 41.6 \\
\hline 15 & Eucalyptus urophylla & 8.817 .3 & \begin{tabular}{|l|l|}
7484 & 3.772 \\
\end{tabular} & & 36 \\
\hline \multicolumn{6}{|c|}{ Jenis tanaman bawah (Under growth) } \\
\hline 10 & Spilanthes grandiflora & - & - & - & 51 \\
\hline 10 & Eupatorium pallescens & - & - & - & 55 \\
\hline 10 & D. dilatatum & - & - & - & 55 \\
\hline 10 & Panicum muticum & - & - & - & 57 \\
\hline 11 & Eucalyptus deglupta & - & - & - & 47 \\
\hline 11 & Eucalyptus trianta & - & - & - & 53 \\
\hline 12 & Penraria javanica & - & - & - & 49 \\
\hline 12 & $\begin{array}{l}\text { Calopogonium } \\
\text { mucunoides }\end{array}$ & - & - & - & 55 \\
\hline 12 & Flemingia congesta & - & - & - & 53 \\
\hline 13 & Lantana camara & - & - & - & 58 \\
\hline 13 & $\begin{array}{l}\text { Saccharum } \\
\text { spontaneum }\end{array}$ & - & - & - & 60 \\
\hline 13 & Anona muricata & - & - & - & 62 \\
\hline 13 & Themedia gigantean & - & - & - & 66 \\
\hline 14 & Pinus falcataria & 20.9 & 74.1 & 5 & - \\
\hline 14 & Acacia mangium & 27.6 & 71 & 0.9 & 68 \\
\hline
\end{tabular}

Sumber (Sources) : (1) Karschon (1967), (2) Lima (1976), (3) George (1978), (4) Poore et al (1985), (5 s/d 15) Pudjiharta $(1985,1986,1988,1991,1992,1994,1995,2001)$ 


\section{REHABILITASI HUTAN DALAM KAITANNYA DENGAN PENYERAPAN AIR OLEH TANAH}

Lahan yang berada di luar kawasan hutan maupun yang berada dalam kawasan hutan yang telah mengalami degradasi (kritis), umumnya lahan tersebut relatif terbuka (tidak tertutup oleh pohon-pohonan), apalagi lahan tersebut terdegradasi karena akibat aktivitas berat seperti aktivitas pertambangan terbuka. Lahan akan mengalami penurunan kesuburan secara fisik maupun kimiawi, mengalami erosi, pemadatan struktur, sulit meresapkan air, suhu permukaan cepat menjadi panas, kelembaban permukaan tanah rendah dan aktivitas biologi termasuk biota tanah sangat kurang.

Adanya rehabilitasi/reboisasi hutan untuk merehabilitasi lahan-lahan terdegradasi tersebut akan merintis adanya tanaman reboisasi yang akan sedikit demi sedikit dapat melindungi dan memperbaiki kondisi lahan tersebut. Dengan tanaman reboisasi, permukaan tanah akan mulai terlindungi dari sengatan radiasi matahari langsung, sehingga suhu permukaan tanah tidak cepat menjadi panas, mengurangi penguapan air dari permukaan tanah, aliran permukaan dapat terhambat oleh adanya tegakan pohon reboisasi dan serasah. Dengan adanya tanaman reboisasi erosipun menjadi terhambat serta kelembaban permukaan tanah dapat terjaga.

Rehabilitasi lahan/hutan terdegradasi dengan jenis-jenis tanaman legum dan tanaman penghasil serasah yang banyak akan cepat memperbaiki sifat kesuburan tanah. Serasah yang dihasilkan oleh tanaman reboisasi akan menjadi sumber bahan organik yang sangat dibutuhkan oleh tanah. Jenis-jenis legum yang dapat bersimbiosis mutualis dengan bakteri nitrogen sangat dibutuhkan oleh tanaman.

Dengan rehabilitasi hutan/lahan diharapkan terjadi perubahan lingkungan mikro yang dibutuhkan bagi aktivitas biologi dan biota tanah. Dengan lingkungan yang berubah akan memungkinkan untuk tumbuh dan berkembangnya aktivitas biologi dan biota tanah serta ketersediaan sumber bahan organik yang berasal dari serasah tanaman hasil reboisasi akan sangat membantu dalam terbentuknya ekosistem biota tanah. Dengan terbentuknya ekosistem biota tanah akan membantu terjadinya proses perkembangan/pertumbuhan perakaran dan aktivitas biologi lainnya. Perubahan kondisi tanah yang demikian akan mempengaruhi/memperbaiki kemampuan tanah dalam meresapkan air.

Rehabilitasi hutan/lahan terdegradasi dengan teknik revegetasi melalui reboisasi dan penghijauan memungkinkan perbaikan kondisi ekosistem biota tanah dan perkembangan aktivitas biologi dan biota tanah yang selanjutnya mempengaruhi kemampuan tanah menyerap air dan menyimpan air, yang pada giliran berikutnya dapat memperbaiki sistem tata air.

Reboisasi yang dilakukan pada kawasankawasan resapan yang terdapat pada daerah aliran sungai (DAS) akan sangat membantu dalam pelestarian kawasan resapan sebagai bagian dari sistem tata air DAS.

\section{REBOISASI/REHABILITASI DAERAH RESAPAN}

Daerah resapan merupakan komponen penting dalam sistem tata air suatu daerah. Tata air dapat diartikan sebagai suatu kondisi alami yang menggambarkan kejadian hidrologi dari sejak penerimaan air hujan, penyimpanan, pengisisan sumber-sumber air, luaran air dan kehilangan air yang terjadi di suatu wilayah/daerah. Proses tersebut seharusnya berjalan secara normal/secara alami dan seimbang. Namun karena suatu intervensi, hal tersebut dapat berubah menjadi tidak seimbang/normal, sehingga terjadi kesenjangan dalam sistem tata air. 
Hal tersebut dapat terjadi karena intervensi aktivitas manusia seperti tata guna lahan dan tata ruang yang tidak sesuai/tidak memperhatikan fungsi-fungsi kawasan dalam sistem tata air. Oleh karena itu, menjaga dan melestarikan daerah-daerah/kawasan yang merupakan daerah resapan air sangat penting untuk menjaga agar sistem tata air tetap berjalan normal.

Dengan adanya aktivitas manusia seperti tersebut di atas dapat mempengaruhi jalannya/proses penyimpanan air, sehingga mempengaruhi pengisian sumber-sumber air, mengecilnya debit mata air/keringnya mata air, hilangnya situ, danau dan rawa.

Air hujan yang diterima pada musim penghujan sebagai sumber penerimaan air menjadi tidak efektif, karena rusaknya sistem penyimpanan air alami, baik dalam profil tanah, lapisan-lapisan tanah/batuan, maupun dalam tubuh perairan seperti situ, danau dan rawa yang terjadi adalah makin meningkatnya proses kehilangan air melalui aliran permukaan masuk ke saluran pembuangan air/drainase, selokan, got, yang dibangun di pemukiman/perkotaan, kawasan industri, kawasan aktivitas lainnya, kemudian masuk ke saluran sungai sehingga sungai cepat mencapai debit puncak yang berarti mempercepat kehilangan air melalui aliran sungai masuk ke laut. Apabila sungai tidak mampu menampung limpahan air dari kawasan tersebut di atas, maka sungai akan meluap/banjir.

Pengerasan permukaan tanah/halaman, fasilitas olah raga/lapangan, jalan-jalan/ gang, dikawasan permukiman/perumahan, dengan beton atau aspal menutup sama sekali kesempatan proses penyimpanan air ke dalam tanah melalui infiltrasi, yang selanjutnya tidak terjadi perkolasi sehingga tidak terjadi pengisisan sumber kelembaban tanah, penurunan permukaan air sumursumur dangkal, dan mulai terasa akan kesulitan mendapatkan air. Untuk mendapatkan air orang menggali sumber-sumber dengan kekuatan pompa air untuk menyedot air ke atas yang mana hal tersebutakan lebih memperburuk keadaan persediaan air dalam tanah.

Sebaliknya dengan pengerasan permukaan tanah seperti di atas, mengakibatkan tingginya koefisien aliran pada kawasan/areal yang diperkeras/kedap air, sehingga curahan air hujan yang diterima pada daerah tersebut sebagian besar akan hilang menjadi aliran permukaan. Aliran permukaan tersebut akan masuk ke saluran/selokan kemudian masuk ke anak sungai/sungai mengakibatkan aliran sungai cepat menjadi besar dan dapat memperbesar banjir yang terjadi.

Banyak teknologi yang sudah dikenal untuk penyimpanan sementara air hujan, yaitu dengan membangun embung, cekungan-cekungan/lubang-lubang dangkal (retarding basin), sumur peresap, sedangkan yang alami seperti situ, danau, dan rawa, di samping sebagai tempat berkumpul/ penyimpanan air di permukaan juga sebagai sumber air permukaan. Namun situ, danau, rawa tersebut sekarang sudah banyak yang tidak berfungsi/hilang.

Teknologi di atas (seperti embung dan lain-lainnya), efektivitasnya sebagai penyimpanan air sementara dan sebagai sumber pengisi sumber-sumber kelembaban tanah dan pengisi sumber air tanah tergantung pada sifat tanah (kapasitas infiltrasi, permeabilitas tanah, dan kapasitas perkolasi). Sedangkan situ, danau, dan rawa yang berfungsi sebagai tempat penyimpanan air saat ini telah banyak berubah fungsi / hilang (akibat penimbunan dan reklamasi), sehingga air yang melimpah saat musim hujan tidak lagi tersimpan/terkumpul dan mengisi situ, danau, dan rawa karena telah berubah fungsi, maka air yang melimpah tersebut akan "liar" mengalir menuju tempat-tempat yang rendah dan menggenangi daerah-daerah lain, seolah-olah daerah banjir telah meluas. Sebelum situ, danau, dan rawa "hilang" daerah genangan terisolir pada sekitar situ, danau, dan rawa sehingga air menjadi menyebar kemana-mana (kondisi ini sering disebut banjir telah meluas).

Efektivitas sumur peresap sangat tergantung pada kedalaman air tanah, debit air tanah, dan radius sumur (volume sumur/volume air dalam sumur). Untuk mencapai volume air dalam sumur yang besar dibutuhkan penyebaran/jumlah sumur-sumur peresap yang tersebar luas dan juga respon masyarakat untuk membangun sumur peresap. Seperti kasus di DKI Jakarta potensi air 
hujan sebesar \pm 3000 juta $\mathrm{m}^{3}$ yang teresap hanya \pm 798 juta $\mathrm{m}^{3}$ atau $\pm 26.6 \%$ selebihnya 2202 juta $\mathrm{m}^{3}$ atau $\pm 73.4 \%$ terbuang, sumur peresap sebanyak \pm 122.000 buah hanya mampu menyerap 73 juta $\mathrm{m}^{3}$ (Haris, 2004).

Teknologi revegetasi/reboisasi dan penghijauan untuk merehabilitasi hutan dan lahan daerah resapan (recharge area) merupakan alternatif yang mendesak agar tata air dapat dipulihkan kembali. Penutupan lahan dengan vegetasi hutan akan lebih efektif dalam meningkatkan penyimpanan dan pengisian sumber-sumber air karena kawasan hutan dan daerah resapan penyebarannya lebih luas. Kawasan hutan dan kawasan resapan seharusnya selalu tertutup vegetasi hutan agar sistem tata air berjalan normal secara alami, sehingga proses penyimpanan dan pengisisan sumber air diharapkan dapat berjalan normal.

\section{BANJIR-KEKERINGAN-TANAH LONGSOR}

Banjir dan kekeringan sangat erat hubungannya dengan tata guna lahan dan tata guna ruang atau tata guna lahan dan tata guna ruang dapat mempengaruhi sistem tata air yang mengakibatkan terjadinya banjir dan kekeringan.

Sistem tata air berkaitan erat dengan penyimpanan air dan pengisian sumber airsumber air secara alami. Apabila proses penyimpanan dan pengisian air tersebut tidak efektif maka proses kehilangan air akan terjadi lebih efektif yang berarti air tidak dapat tersimpan dalam tanah dan tidak dapat mengisi sumber-sumber air dalam tanah (kelembaban tanah dan air tanah), tetapi hilang sebagai aliran permukaan yang mengakibatkan tingginya volume aliran permukaan yang dapat menimbulkan banjir/genangan dan sebagai air yang tidak termanfaatkan. Dengan demikian maka banjir yang terjadi di musim penghujan selain sebagai bencana, juga merupakan proses percepatan pengeringan/kehilangan air sehingga persediaan air di musim kemarau berikutnya mengalami kehilangan air/kesulitan air.

Salah satu dari beberapa bentuk penggunaan lahan adalah penutupan lahan dengan hutan. Penutupan hutan pada daerah hulu yang umumnya merupakan daerah tangkapan air (head water catchment) sangat penting dalam sistem tata air DAS, karena daerah tersebut (hulu) merupakan juga pemasok air (recharge area) bagi zone-zone mata air dibawahnya. Apabila kondisi hutan pada daerah hulu yang umumnya merupakan daerah bergunung/pegunungan dalam kondisi baik maka diharapkan kondisi tata airnya baik pula. Menurut Hewlett dan Mutter (1969) bahwa daerah hulu yang tertutup hutan yang baik maka $80-85 \%$ total aliran adalah berasal dari aliran dasar yang ditopang oleh aliran perlahan-lahan dari "zone of aeration", selebihnya adalah aliran langsung.

\section{A. Banjir}

Banjir selain disebabkan oleh penyebab banjir yang umum terjadi, juga sebagai akibat dari erosi yang berkelanjutan dan tidak ditangani secara serius. Akibat erosi seperti terjadi sedimentasi pada dasar sungai, saluran, selokan dan fasilitas drainase lainnya mengakibatkan penurunan kapasitas saluran untuk menampung dan mengalirkan air bahkan dapat terjadi penyumbatan sehingga air mudah meluap.

Agar lebih jelas untuk menelusuri penyebab dan faktor yang mempengaruhi banjir, disampaikan sebagai berikut:

Banjir umumnya disebabkan oleh :

1) Mencairnya salju, terjadi pada negara-negara yang diliputi salju. 
2) Air pasang, biasa terjadi pada negara-negara pantai samudra/lautan seperti, Bangladesh, India, Filipina.

3) Hujan badai atau siklon tropis yaitu hujan yang sangat tinggi (ekstrim) yang terjadi pada waktu lama dan meliputi daerah luas, Indonesia sering mengalaminya. Penyebab butir 2 dan 3 dapat terjadi bersamaan.

4) Pengendapan hasil erosi pada saluran dan sungai yang mengakibatkan penyempitan, pendangkalan dan penyumbatan saluran.

5) Aktivitas manusia yang dapat merusak mekanisme tata air alami, hal ini umumnya terjadi karena perubahan penutupan lahan/penggunaan lahan.

Adapun faktor-faktor yang mempengaruhi banjir antara lain :

1) Pola susunan anak sungai (pola aliran)

2) Kondisilereng

3) Kondisi saluran/sungai (meander)

4) Keberadaan/kemanpuan penyimpanan air pada depresi permukaan (reservoir)

5) Kondisi vegetasi penutup

6) Kondisi kekasaran permukaan

7) Kemampuan infiltrasi

8) Ukuran/bentukDAS.

Untuk mudahnya dibentuk diagram seperti pada Gambar 1.

Apabila dilihat dari penyebabnya, maka untuk mengurangi bahaya banjir adalah mengurangi penyebab banjir butir 4) dan butir 5) sedang penyebab banjir butir 1), 2), 3) tergantung pada alam. Sedang faktor-faktor yang berpengaruh pada banjir yang dapat diperkecil pengaruhnya adalah : butir 3), 4), 5), 6) dan 7). Faktor 3) dapat dipengaruhi oleh adanya aktivitas yang mempertinggi kapasitas tampung saluran, melengkapi saluran by pass, pemeliharaan saluran (dasar, pinggiran/tebing, tanggul). Untuk faktor 4), 5), 6) dan 7) dapat dipengaruhi dengan memperbaiki/memelihara semua bentuk reservoir yang ada atau membangun yang baru, memperbaiki kondisi hutan/vegetasi penutup.

Upaya memperbaiki vegetasi penutup lahan secara tidak langsung dapat memperkecil pengaruh lereng terhadap kecepatan aliran (butir 2). Karena itu dengan teknik revegetasi (memperbaiki kondisi vegetasi penutup lahan (hutan) akan dapat memperkecil pengaruh lereng (butir 2) pada kecepatan aliran dan mempertinggi kemampuan butir 4), 5), 6) dan 7) dalam mengurangi banjir.

\section{B. Banjir Bandang}

Banjir bandang terjadi umumnya didahului oleh hujan yang beruntun dengan intensitas yang tinggi. Hujan yang terjadi sampai beberapa hari/minggu sebelumnya dengan intensitas tinggi dan waktu yang relatif lama akan merintis terjadinya banjir bandang. Hujan tersebut akan meningkatkan kejenuhan air dalam tanah (mengisi semua bentuk penampungan air pada tanah) sehingga akan melemahkan struktur tanah di wilayah yang diguyur hujan dan mengakibatkan tanah/lahan menjadi labil. Kondisi tersebut melemahkan kekuatan/kekompakan tanah/lahan untuk menahan berat 


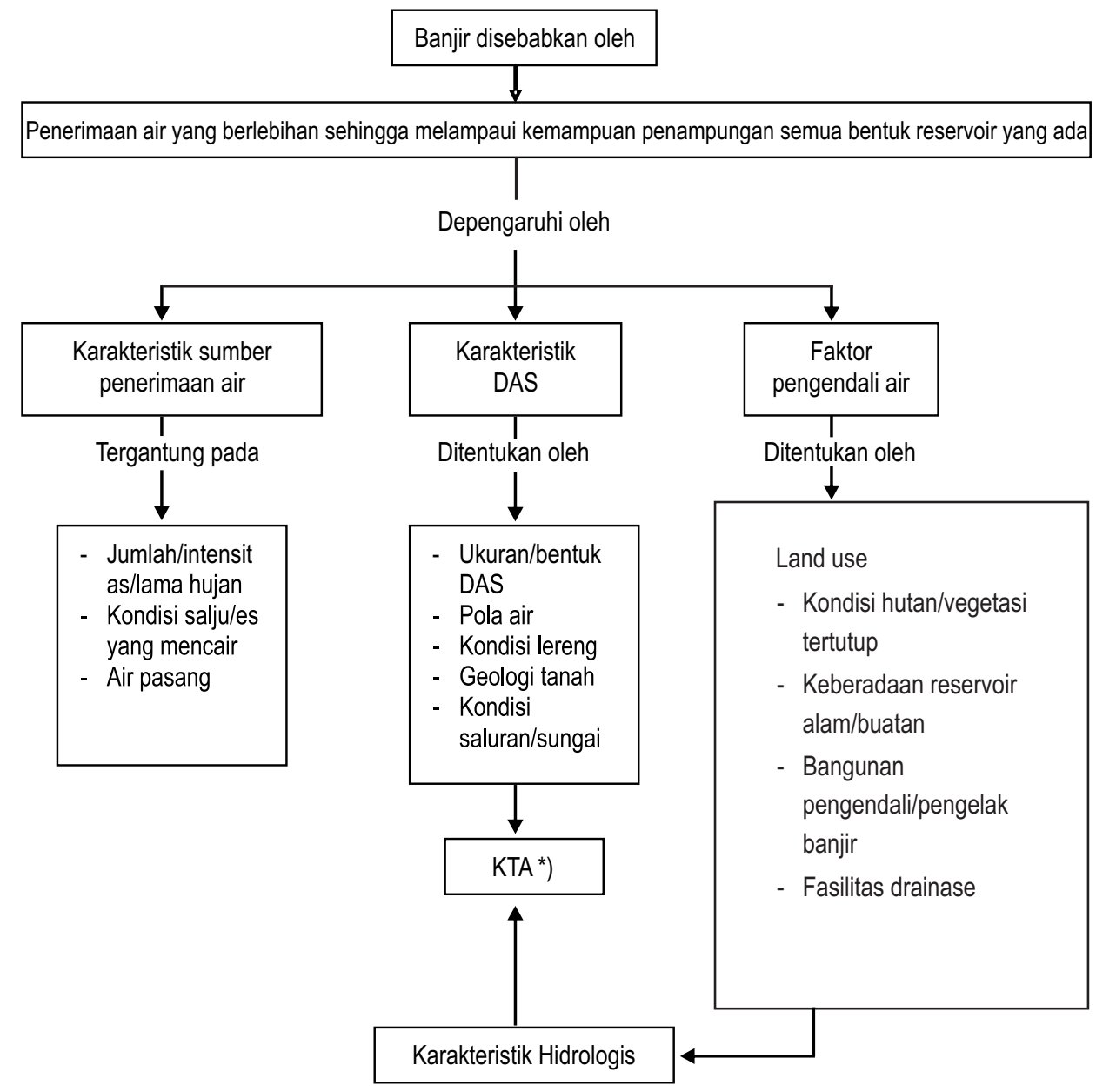

*) KTA : Konservasi Tanah dan Air

Gambar 1. Diagram proses banjir

Figure 1. Flood procees diagram

massanya dan beban yang ada padanya. Akibatnyat dapat terjadi mass washing, mud flow, sand flow, debris avalanches, debris flow. Pada kondisi yang sudah demikian kritis, seperti di atas bila terjadi hujan lebat (dengan intensitas) yang relatif tinggi maka lahan yang sudah labil walaupun berhutan (tertutup hutan) tidak akan mampu lagi menahan curahan hujan tersebut, sehingga kondisi yang rawan/labil yang terjadi pada hujan sebelumnya, pada hujan berikutnya akan terjadi banjir besar yang tak tertahan lagi oleh faktor pengendali alami seperti hutan. Banjir tersebut biasanya disebut banjir bandang yang mampu menghanyutkan berbagai macam material akibat adanya mass washing/mud flow/sand flow/debris flow/debris avalanches bersama-sama aliran banjir tersebut. 
Fungsi hutan sebagai faktor pengendali aliran bukan tidak tak terbatas kemampuannya, tetapi dipengaruhi oleh besar atau kecilnya massa air yang tercurah dari atmosfer/hujan, dan kondisi topografi/lereng dan geologi/tanah. Bila hujan yang tercurah melebihi kemampuan lahan maka lahan akan labil karena struktur tanah melemah. Hutan yang berada diatas tanah/lahan yang demikian akan goyah, apalagi diterpa hujan lebat, pada kondisi seperti itu, maka banjir bandang tak tertahankan lagi.

\section{Kekeringan}

Kondisi kekurangan air merupakan masalah yang bertolak belakang dengan kedua masalah diatas (erosi dan banjir). Masalah erosi dan banjir berhubungan dengan kondisi banyaknya air/besarnya air yang mengalir dan tidak/kurang terkendali, sedang kekeringan adalah masalah yang berhubungan dengan ketiadaan/kekurangan air.

Kondisi ini (kekeringan) ada yang disebabkan oleh karena kondisi iklim (iklim kering, arit, gurun), tetapi ada yang merupakan akibat aktivitas manusia, Indonesia yang terletak pada daerah iklim tropis mempunyai 2 (dua) musim yaitu musim penghujan dan musim kemarau. Kedua musim tersebut silih berganti, sehingga sebenarnya pergantian musim yang dapat mempengaruhi kondisi persediaan air sudah dapat diperkirakan kejadiannya. Pada musim penghujan kondisi persediaan air berlebihan sehingga dapat menimbulkan banjir, sedang pada musim kemarau kondisi persediaan air menjadi berkurang.Yang menjadi permasalahan sebenarnya adalah bagaimana upaya mengguna-kan/memanfaatkan air ketika kondisi berlebihan untuk cadangan pada saat kondisi persediaan air kurang. Ada beberapa aktivitas manusia yang justru dapat membantu terjadinya kondisi persediaan air berkurang. Aktivitas/tindakan manusia yang dapat mendorong kepada kondisi kekurangan persediaan air antara lain adalah:

a) Pengeringan sumber-sumber air permukaan seperti rawa, danau dan situ.

b) Eksplorasi air tanah secara berlebihan, sehingga mengakibatkan penurunan permukaan air tanah, penurunan permukaan air tanah ini akan permanen apabila tidak ada pengendalian.

c) Pembukaan hutan secara berlebihan sehingga mengganggu sistem tata air wilayah sekitarnya.

Rawa, danau dan situ atau semua bentuk penampung dan penyimpan air di permukaan tanah berfungsi sebagai sumber air yang dapat memasok air ke pada sumber air tanah. Pengalihan/perubahan fungsi rawa, danau, situ dan bentuk penampungan air permukaan untuk keperluan lain seperti, permukiman, pusat-pusat kegiatan ekonomi dan sebagainya dapat mengakibatkan terganggunya sistem tata air, sehingga proses pengisian sumber air tanah terganggu akibatnya daerah sekitar mengalami kekurangan/kesulitan air.

Rawa, danau, dan situ umumnya merupakan basin, atau cekungan yang berisi air. Apabila cekungan tersebut digunakan untuk kepentingan lain seperti untuk permukiman, maka wilayah tersebut akan rawan genangan (banjir) pada saat terjadi hujan yang ekstrim tinggi, dan air hujan yang besar tersebut mengalir/menuju/mencapai tempat-tempat yang lebih rendah. Rawa, danau, dan situ adalah cekungan yang lebih rendah dibandingkan tempat-tempat sekitarnya.

Eksplorasi air tanah secara berlebihan lebih-lebih sampai pada air tanah dalam untuk keperluan sehari-hari dengan menggunakan pompa kapasitas tinggi; dapat mengakibatkan penurunan permukaan air tanah. Akibatnya adalah penurunan permukaan air tanah sekitarnya sehingga sumur-sumur penduduk akan menurun airnya bahkan kering, sehingga persediaan air untuk penduduk menjadi sulit. Penurunan permukaan air tanah dapat menarik masuknya air laut ke darat (intrusi air laut). Kondisi ini dapat terjadi pada kota-kota pantai, termasuk Jakarta. 
Pembukaan hutan secara berlebihan dapat mengganggu sistem tata air disekitarnya. Hutan alam yang tersebar di lereng-lereng gunung dan pegunungan umumnya merupakan tempat-tempat sumber mata air (munculnya mata air). Mata air yang sumber airnya berasal dari daerah hulu yang berhutan umumnya airnya kontinu sepanjang tahun. Hal tersebut terjadi melalui proses yang panjang dari air hujan yang jatuh pada daerah hulu yang berhutan akan lebih mempunyai kesempatan untuk meresap kedalam lantai hutan (lapisan serasah), kemudian masuk ke lapisan humus kemudian ke lapisan tanah, masuk ke profil tanah yang lebih dalam dan mengisi sumber air tanah, kemudian muncul di suatu tempat sebagai mata air. Apabila hutannya ditebang/dibuka secara berlebihan maka proses pengisian sumber air tanah terganggu, karena air hujan yang jatuh di daerah hulu yang tidak berhutan, maka kesempatan air hujan untuk meresap ke dalam tanah menjadi kecil, karena hilangnya tegakan pohon hutan dan serasah, sehingga air hujan lebih banyak menjadi aliran permukaan yang mengakibatkan erosi. Apabila hal tersebut terjadi pada saat hujan yang besar dan berkepanjangan selama musim penghujan, dapat terjadi banjir bandang yang menimpa daerah hilirnya.

Setelah musim penghujan selesai, permukaan tanah yang terbuka (akibat pembukaan hutan) akan langsung menerima panas radiasi matahari sehingga proses penguapan air dari permukaan tanah cepat meningkat, permukaan menjadi kering, sehingga produktivitas tanah menurun karena kekeringan, aktivitas mikroba tanah hilang.

Kurangnya kesempatan air hujan meresap ke lapisan tanah yang permukaannya terbuka lebih-lebih pada daerah hulu (berlereng), maka proses pengisian sumber air tanah terganggu, akibatkan pasokan air tanah ke sumber mata air terganggu, sehingga mata air menjadi kecil, bahkan mata air mati. Akibat selanjutnya adalah kesulitan air bagi daerah bawahnya.

Pembukaan hutan dengan sistem tebang habis umumnya dilakukan pada hutan tanaman. Permasalahan erosi, banjir dan kekeringan seperti yang diuraikan diatas akan terjadi pada kawasan bekas penebangan (tebang habis) setelah hujan turun. Hal tersebut dapat dihindari dengan teknikteknik penebangan yang memperhatikan norma-norma konservasi tanah dan air.

Upaya yang penting untuk daerah-daerah yang mempunyai curah hujan yang tinggi adalah mengupayakan meningkatkan penghasilan air dari sumber air berupa lengas tanah dan air tanah, upaya ditekankan pada pelancaran infiltrasi untuk mengisi lengas tanah dan pelancaran perkolasi untuk mengisi air tanah dan menghidupkan mata air sebagai pembekal air sungai, pelancaran ilfiltrasi dan perkolasi sekaligus berguna mengurangi kehilangan air berupa aliran limpas.

\section{Tanah Longsor}

Tanah longsor (land slide) dapat terjadi pada lokasilokasi yang mempunyai kondisi geologi spesifik berlereng miring, curah hujan tinggi. Yang dimaksud dengan kondisi geologi spesifik adalah adanya permukaan yang berfungsi sebagai bidang luncur yang miring, bidang luncur tersebut kedap air, sehingga air hujan yang meresap kedalam tanah yang berada di atas bidang luncur setelah terjadi hujan besar/lama, disamping mengakibatkan tanah diatas bidang luncur labil, air tersebut mencapai permukaan lapisan yang kedap air tersebut. Apabila massa air yang mencapai bidang luncur yang kedap air tersebut cukup besar dan mampu menggerakan massa tanah yang ada diatasnya mengikuti kemiringan bidang luncur, maka tanah diatasnya yang sudah labil akan tergelincir, meluncur terbawa massa air yang bergerak dipermukaan bidang luncur, maka proses tanah longsor (land slide) terjadi dan mampu membawa dan menggelincirkan apa saja yang berada diatas dan di dalam massa tanah tersebut. 
Faktor penyebab dan faktor yang berpengaruh terjadinya tanah longsor sangat sulit dikendalikan yaitu : kondisi geologi yang spesifik, curah hujan yang relatif tinggi, dan kemiringan lereng. Massa tanah hasil proses tanah longsor (land slide) dapat terhenti dan terkumpul pada suatu tempat/lokasi. Massa tanah tersebut dalam kondisi labil dan tetap berbahaya apabila ada hujan yang cukup besar dan mampu membawa/ menyangkut/menghanyutkan massa tanah hasil longsoran tersebut. Peristiwa ini bukan tanah longsor tetapi dapat berupa mud flow/sand flow. Mud flow/sand flow dapat terjadi tidak hanya dari massa tanah hasil longsor (land slide) tetapi dapat terjadi dari massa tanah yang runtuh (debris avalanches), kemudian terbawa oleh aliran air/banjir. Debris avalanches tidak terjadi pada bidang luncur, tetapi biasanya terjadi karena tidak mampu menahan berat massanya sehingga runtuh.

Untuk mengurangi ancaman bahaya tanah longsor perlu langkah-langkah preventif seperti :

- Inventarisasi dan identifikasi daerah-daerah/lokasi-lokasi rawan longsor yaitu lokasi-lokasi yang mempunyai geologi spesifik yang diduga rawan longsor.

- Pemetaan lokasi-lokasi yang diduga rawan longsor secara jelas dengan skala besar agar mudah diketahui dilapangan.

- Menentukan batas-batas di lapangan daerah-daerah yang diduga kena dampak oleh adanya tanah longsor yang mungkin terjadi.

- Pasang rambu-rambu, peringatan pada tempat-tempat yang mudah dibaca untuk menjauhi lokasi/kawasan yang diduga rawan longsor dan larangan beraktivitas/bermukim dilokasi/kawasan tersebut.

- Informasi dan penyuluhan kepada masyarakat yang berada disekitar lokasi yang diduga rawan longsor agar keluar, menjauhi lokasi/kawasan tersebut.

- Lokasi yang diduga rawan longsor, apabila mungkin dijadikan kawasan hutan yang bebas dari aktivitas budidaya (hutan tutupan) dalam pengawasan yang intensif. Adanya hutan tutupan tersebut diharapkan dapat menghambat proses terjadinya land slide.

\section{TATA GUNA LAHAN DAN AIR JANGKA PANJANG}

Tantangan masa depan adalah kecenderungan dan kebutuhan sumber daya alam seperti: air dan lahan tidak dapat terlepas dari kondisi ketersediaan sumber daya alam dan kebutuhan sumber daya alam. Hal tersebut dapat menimbulkan ketidakseimbangan antara kebutuhan dan ketersediaan sumber daya alam.

Beberapa kecenderungan tersebut antara lain :

- Keterbatasan sumber air bersih, persediaan air berkurang, sumber mata air menurun, tingginya biaya proyek-proyek air bersih sehingga biaya perkubik air meningkat.

- Ketergantungan pada musim, sedangkan fenomena perubahan iklim yang mempengaruhi musim makin sulit diprediksi.

- Kebutuhan air dan lahan meningkat, sebagai akibat meningkatnya jumlah penduduk.

- Peningkatan kontaminasi sebagai akibat peningkatan aktivitas manusia sehingga memerlukan tambahan biaya untuk teknologi pembuangan polutan maupun teknologi daur ulang.

- Keterbatasan lahan dan air mengakibatkan produksi pertanian tidak mencukupi kebutuhan pangan yang meningkat sesuai dengan perkembangan penduduk.

- Rendahnya investasi, kekurangan sumber daya alam dan dana, kondisi social dan masalah lingkungan, kurangnya perhatian akan upaya pelestarian dan konservasi serta efisiensi produksi dan penggunaan sumber daya alam akan memperberat krisis yang dialami. 
- Rusaknya sistem tata air seperti tingginya debit aliran sungai pada musim hujan sebaliknya menurunnya debit sungai, merosotnya debit mata air pada musim kemarau, sistem hidrologi DAS. Kondisi demikian apabila berlangsung terus semakin lama semakin meningkat dari segi jumlah DAS yang rusak sistem hidrologinya maupun dari segi tingkat kerusakannya sebagai akibat rusaknya lingkungan tata air karena aktivitas manusia, sehingga membutuhkan dana dan waktu yang tidak sedikit untuk merehabilitasinya.

- Kecenderungan tersebut semakin terasa terutama pada musim kemarau yang panjang dan masalah ancaman banjir yang selalu mengancam setiap tahun pada musim penghujan.

Dari hal-hal di atas terlihat bahwa dalam menghadapi banjir dan kekeringan yang memang merupakan spesifik dari iklim tropis yang mempunyai 2 musim (musim penghujan dan musim kemarau), masalah sebenarnya adalah:

- Bagaimana mengupayakan agar kondisi yang kontradiktif antara musim penghujan (banjir) dan musim kemarau (kekurangan air) menjadi tidak terlalu tajam.

- Bagaimana mengelola/memanfaatkan/memanen air yang melimpah pada musim penghujan sebagai persediaan air untuk mengisi sumber-sumber air untuk persediaan pada musim kemarau, pada dimensi kualitas, kuantitas, ruang, dan waktu, sehingga ancaman banjir terkendali dan ancaman kekeringan teratasi.

- Siapa yang merencanakan, yang melaksanakan, yang berwenang, dan siapa yang bertanggung jawab kepada siapa

Lahan dan air keduanya merupakan bagian dari ekosistem DAS. Karena itu penanganan jangka panjang untuk kedua sumber daya tersebut tidak dapat terlepas dari pengelolaan DAS, sebagai unit ekosistem. DAS juga merupakan unit tata air yang didalamnya mempunyai satu sistem sungai yang saling berhubungan demikian rupa sehingga semua aliran yang berasal dari daerah tersebut keluar melalui satu sungai induk (utama).

DAS sebagai unit wilayah aliran/sistem sungai yang dibatasi oleh topografi yang umumnya berupa punggung pegunungan, perbukitan dan gunung, biasanya disebut sebagai daerah hulu dan sebagai daerah tangkapan air (head water catchment) yang harus terlindung, teramankan dan terjaga fungsinya sebagai daerah tangkapan air, peresapan air, dan pemasok air (recharge area) bagi daerah-daerah dibawahnya (daerah tengah dan hilir).

Daerah hulu (head water catchment), daerah pemasok air dan daerah peresapan air harus terlindung dengan vegetasi hutan yang baik agar kemampuan untuk menyimpan air terjaga kemudian melepaskan air tersebut secara teratur dan perlahan-lahan melalui mata air yang tersebut pada zone-zone mata air dibawahnya di daerah tengah dan hilir.

Tata ruang dan tata guna lahan didaerah hulu harus ditangani secara serius karena dapat berdampak besar bagi daerah bawahnya (tengah dan hilir). Tata ruang dan tata guna lahan yang tidak sesuai dengan fungsi daerah hulu dapat menganggu sistem tata air dan berdampak buruk bagi daerah bawahnya (tengah dan hilir).

Karena itu tata guna lahan harus sesuai dengan tata ruang, tata ruang harus sesuai dengan karakteristik biofisik, social ekonomi masyarakat, dan fungsi-fungsi kawasan. Tata ruang mengutamakan kelestarian fungsi-fungsi kawasan berdasarkan karakteristik fisik, iklim dan hidrologi, tata guna lahan mengutamakan kelestarian produktivitas lahan, pengembangan tata guna air mengutamakan pemanfaatan perolehan/penerimaan air secara optimal untuk pengisian dan persediaan sumber-sumber air, penanaman pohon/tanaman memperhatikan tujuan penanaman dan kesesuaian dengan iklim dan lahan serta jenis-jenis pohon yang sesuai dengan tujuan, sistem/pola tanam yang mendukung tata air. 
Perlu segera dibentuk suatu Lembaga Tingkat Nasional yang bertanggung jawab dalam penyusunan perencanaan, pengelolaan serta evaluasi sumber daya alam dalam DAS. Kebijakan penyusunan perencanaan pengelolaan tersebut merupakan kesepakatan yang bulat dan terpadu dari semua sektor, semua kepentingan, dan semua wilayah, karena itu keberadaan lembaga tersebut sangat mendesak dan urgent. Kebijakan yang selama ini dilakukan secara sektoral perlu dikoordinasikan/ diintegrasikan untuk kepentingan bersama oleh adanya lembaga tersebut. Lembaga tersebut dibentuk berdasarkan hukum yang kuat. Alur pikir perlunya kewenangan dan kelembagaan disajikan pada Gambar 2.

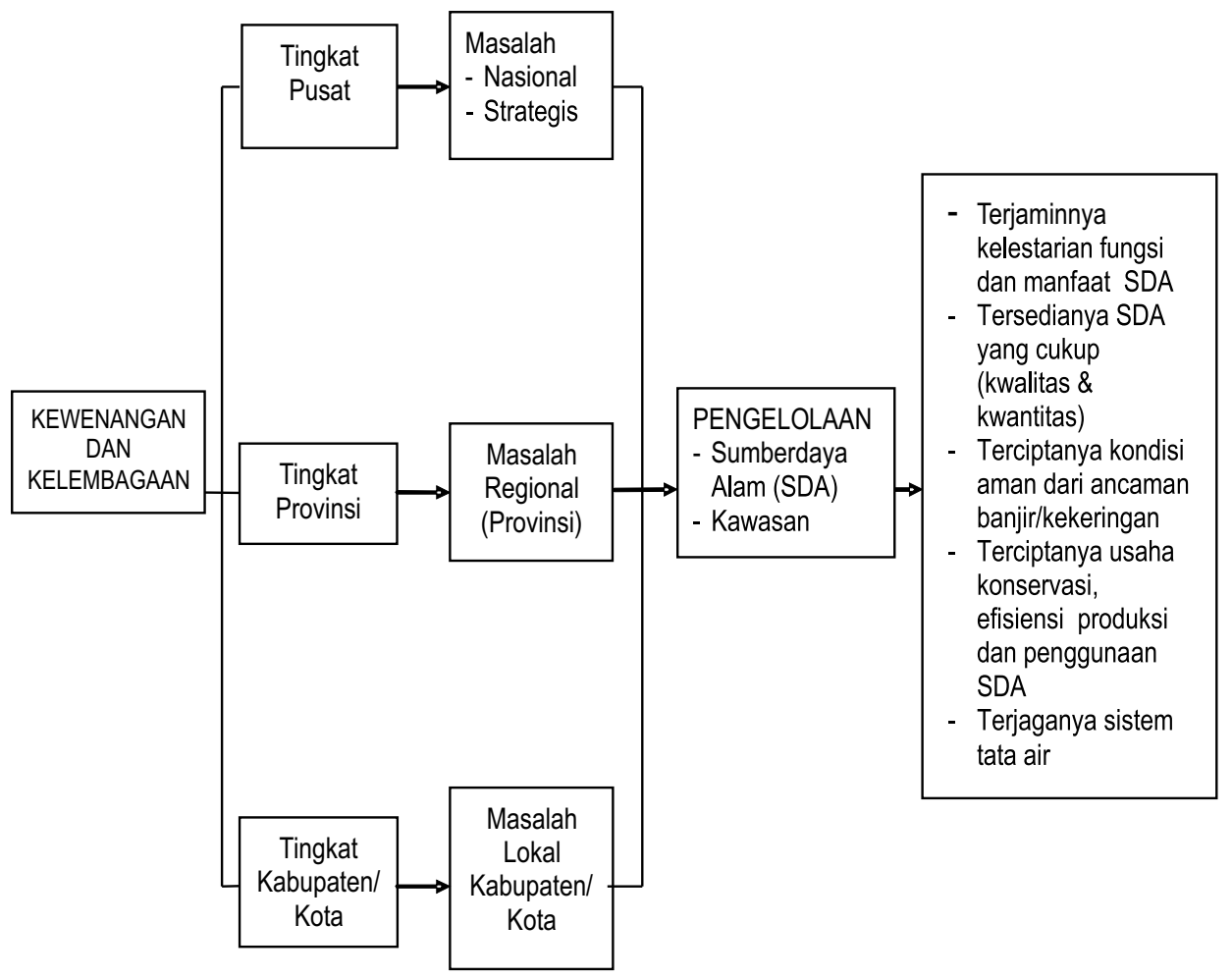

Gambar 2. Alur pikir perlunya kewenangan dan kelembagaan Figure 2. Flow chart of the importance of authority and institution 
Beberapa Undang-Undang, Peraturan Pemerintah dan Keputusan Presiden yang berkaitan dengan pengelolaan sumber daya alam perlu dikaji dan dievaluasi kemudian diintegrasikan agar tidak bersifat sektoral. Adapun beberapa Undang-Undang, Peraturan Pemerintah dan Keputusan Presiden tersebut dapat dilihat pada Lampiran I.

\section{KESIMPULAN}

Pengamanan jangka panjang penggunaan lahan dan air sebaiknya berbasis pada satuan pengelolaan DAS, dilakukan secara terpadu sejak dari penyusunan perencanaan pengelolaan, pelaksanaan pengelolaan, pengawasan dan pengendalian, monitoring dan evaluasi. Keterpaduan tersebut meliputi semua sektor, semua kepentingan dan semua daerah dihulu, ditengah, dan dihilir/muara yang merupakan rangkaian kegiatan yang tak terpisah.

Untuk menjaga kontinuitas sumber-sumber air, upaya yang penting adalah memanen air yang melimpah pada musim penghujan untuk pengisian sumber-sumber air dan penyediaan air di musim kemarau berikutnya. Upaya ini sangat penting untuk pengendalian banjir (kehilangan air melalui banjir) dan untuk memperkecil ancaman kekeringan.

Peninjauan kembali tata ruangtata guna lahan khususnya pada kawasan head water catchment/recharge area yang tidak sesuai untuk di tata ulang agar fungsi-fungsi kawasan sebagai recharge area dan head water catchment efektif kembali, hal ini sangat penting untuk memperbaiki sistem tata air.

Untuk melakukan hal-hal di atas serta tercapainya keterpaduan seperti yang dimaksudkan di atas, diperlukan adanya lembaga Tingkat Nasional yang kuat dan berwibawa secara hukum dan mampu mengintegrasikan semua kepentingan, semua sektor dan semua wilayah, dan mampu menyusun perencanaan terpadu, pelaksanaan terpadu, pengawasan dan pengendalian. Lembaga Tingkat Nasional tersebut penting untuk menciptakan kejelasan siapa berbuat apa (who doing what) dan penataan kewenangan (restructuring authorities), sehingga jelas batas-batas kewenangan, berdasarkan perundang-undangan dan peraturan-peraturan yang berlaku. 
Lampiran 1. Undang-Undang, Peraturan Pemerintah dan Keputusan Presiden berkaitan dengan pengelolaan semberdaya alam.

Undang-Undang:

1. Undang-Undang No. 5 Tahun 1960 tentang Peraturan Dasar Pokok-PokokAgraria.

2. Undang-Undang No. 11 Tahun 1974 tentang Pengairan

3. Undang-Undang No. 5 Tahun 1990 tentang Konservasi Sumber Daya Alam Hayati dan Ekosistemnya.

4. Undang-Undang No. 12 Tahun 1992 tentang Sistem Budidaya Tanaman

5. Undang-Undang No. 24 Tahun 1992 tentang Penataan Ruang.

6. Undang-Undang No. 23 Tahun 1997 tentang Pengelolaan Lingkungan Hidup.

7. Undang-Undang No. 22 Tahun 1999 tentang Pemerintah Daerah.

8. Undang-Undang No. 41 Tahun 1999 tentang Kehutanan.

9. Undang-Undang No. 7 Tahun 2004 tentang Sumber DayaAir.

Peraturan Pemerintah:

1. Peraturan Pemerintah No. 22 Tahun 1982 tentang Tata Pengaturan Air.

2. Peraturan Pemerintah No. 23 Tahun 1982 tentang Irigasi.

3. Peraturan Pemerintah No. 20 Tahun 1990 tentang Pengendalian Pencemaran Air.

4. Peraturan Pemerintah No. 35 Tahun 1991 tentang Sungai.

5. Peraturan Pemerintah No. 69 Tahun 1996 tentang Pelaksanaan Hak dan Kewajiban serta Bentuk dan Tata Cara Peran Serta Masyarakat dalam Penataan Ruang.

6. Peraturan Pemerintah No. 47 Tahun 1997 tentang Rencana Tata Ruang Wilayah Nasional.

7. Peraturan Pemerintah No. 27 Tahun 1999 tentang Analisa Mengenai Dampak Lingkungan.

8. Peraturan Pemerintah No. 93 Tahun 1999 tentang Perusahaan Umum (Perum) Jasa Tirta I.

9. Peraturan Pemerintah No. 94 Tahun 1999 tentang Perusahaan Umum (Perum) Jasa Tirta Il.

10. Peraturan Pemerintah No. 25 Tahun 2000 tentang Kewenangan Pemerintah Daerah dan Kewenangan Propinsi sebagai Daerah Otonomi.

11. Peraturan Pemerintah No. 30 Tahun 2003 tentang Perusahaan Umum Perhutani.

12. Peraturan Pemerintah No. 77 Tahun 2001 tentang Irigasi.

Keputusan Presiden:

1. Keputusan Presiden No. 3 Tahun 1963 tentang Penertiban Pembangunan Baru Sepanjang JalanAntar Jakarta Bogor Cianjur.

2. Keputusan Presiden No. 48 Tahun 1983 tentang Penataan ruang dan Penertiban serta Pengendalian Pembangunan Pada Kawasan Pariwisata Puncak dan Wilayah Jalan Jakarta Bogor Puncak Cianjur di Wilayah luar DKI, Kodya Bogor, Kotif Depok, kota Cianjur, Kota Cibinong.

3. Keputusan Presiden No. 84 Tahun 2000 tentang Pedoman Organisasi Perangkat daerah.

4. Keputusan Presiden No. 79 Tahun 1985 tentang Penetapan Rencana Umum Tata Ruang Kawasan Puncak.

5. Keputusan Presiden No. 32 Tahun 1980 tentang Pengelolaan Kawasan Lindung.

6. Keputusan Presiden No. 75 Tahun 1993 tentang Koordinasi Pengelolaan Tata Ruang Nasional.

7. Keputusan Presiden No. 114 Tahun 1999 tentang Penataan Ruang Kawasan Bogor-PuncakCianjur.

8. Keputusan Presiden No. 123 Tahun 2001 tentang Tim Koordinasi Pengelolaan Sumber Daya Air. 


\section{DAFTAR PUSTAKA}

Anonim. 1991. Global Warning. World Water and Evironmental Enginer. p. 36-37

Frebuary, Ed. C, W.D. Stoek, W.J. Bond, D.J. Le Raux. 1995. Relationship Between Water Availability and Selected Vessel Characterisctic in Eucalyptus Grandis and Two Hybrids. IAWA Journal 16 (3).p. 269-276.

Haris. 2004. Potret Jakarta. Informasi Singkat. Lokakarya Perubahan Iklim dan Implikasi Terhadap BencanaAlam di DKI JakartaAntisipasi dan Mitigasi Dampak Kemarau-Banjir. Jakarta

Hewlett, J. D. and W. L. Mutter, 1969. An Outline of Forest Hydrology School of Forest Resources University of Georgia, p. 87-104

George, M. 1978. Interception, Stem Flow and Through Fall in an Eucalyptus Hybrid Plantation. Indian Forestry 11 (104) 719-726.

Lima, W. P. 1976. Interceptacao de Chuva Em Pavoamentos de Eucalipto e de Pinheiro PEF (13) 75 90 dalam M.E.D Poorc and C. Frees 1985. The Ecologycal Effects of Eucalyptus FAO Forestry Paper 59:11-12.

Karschon, Rand D. Heth. 1967. The Water Balance of Plantation Eucalyptus camaldulensis Dehn. Contribution on Eucalyptus in Israel III. Ilanot And Kiriat Hayim Israel 7-34 and La Yaaran 17 (l).

Poore. M. E. D. and C. Fries. 1985. The Ecological Effects of Eucalyptus. FAO Forestry Paper 59 : 187.

Pudjharta, Ag. dan M. K. Salata. 1985. Aliran Batang, Air Lolos dan Intersepsi Curah Hujan Pada Tegakan Pinus Merkusii di Daerah Hutan Tropik Cikole, Lembang, Bandung Utara, Jawa Barat. Buletin Penelitian Hutan 471 : 49-62.

Pudjharta, Ag. 1986. Aspek Hidrologi Tegakan Parkia Javanica, Sweetenia Macrophylla dan Pinus Merkusii Pada Penelitian Lisimeter Di Bogor. Buletin Penelitian Hutan 487 : 1-12.

Pudjharta, Ag. dan Irfan Budi Pramono. 1988. Pengaruh Jenis Tegakan Terhadap Transfer Air. Buletin Penelitian Hutan 499: 1-9.

Pudjharta, Ag. dan Tyas Mulia Basuki 1995. Intersepsi curah hujan pada tegakan Agathis Iorantifolia. Bulletin Penelitian Hutan 570 : 1-9.

Pudjiharta, Ag. 1991. Aspek Hidrologis Jenis Pohon Dalbergia Latifolia, Shorea Pinanga dan Acacia Mangium. Buletin Penelitian Hutan 542 : 1-7. Pusat Penelitian Dan Pengembangan Hutan Bogor.

1991. Respon dari Beberapa Jenis Tanaman Bawah Terhadap Tata Air. Buletin Penelitian Hutan $543: 1-8$.

1992. Kebutuhan Air Jenis Eucalyptus. Buletin Penelitian Hutan 553:1-8.

1994. Evapotranspirasi Beberapa Jenis Tanaman Bawah. Buletin Penelitian Hutan 562 : 1 16. 
1995. Respon Beberapa Jenis Tanaman Bawah Terhadap Evapotranspirasi di Waspada Garut. Buletin Penelitian Hutan 582 : 1-16.

1995. Aspek Biogeohidrologi Pada Jenis Tegakan A. falcataria dan A. mangium. Buletin Penelitian Hutan 587 : 1-30.

1997. Aplikasi Petunjuk Pemilihan Jenis Dalam Kaitannya Dengan Proporsi Curah hujan dan Evapotranspirasi (Jenis P. merkusii, Eucalyptus sp, dan A. mangium) dan Peluang Perolehan Air.Info Hutan 84 : 1-15.

2001. Pengaruh Hutan Tanaman Industri Eucalyptus sp. Terhadap Tata Air di Jawa Barat . Buletin Penelitian Hutan 628: 1-12. 